\title{
Constructivism Foreign Language Listening Teaching
}

\author{
Xiaoxia Li \\ School of Foreign Languages, Dalian Jiaotong University, Dalian, China \\ kasumi.so@163.com
}

\begin{abstract}
The constructivism theory is student-oriented, emphasizing that the students should actively explore and discover the knowledge, and construct their own knowledge structure. This article takes the constructivism theory as the guidance and students as the main subject, by setting up a realistic scenario so as to encourage independent learning and collaborative learning, and tries to discuss the influence of teaching mode with the sense-making theory as the ultimate goal towards the foreign language listening teaching.

Index Terms - Constructivism, Foreign Language, Listening Teaching
\end{abstract}

Listening teaching has long been neglected by teachers and students in foreign language teaching. In listening teaching, it is common that only teachers speak and explain the dialogues in the textbooks while the students seldom have the chance to practice, causing the listening class a quite boring course. In addition, in order to improve students' test-taking ability, the teachers may easily set the teaching purposes of listening class as how to achieve better scores in the foreign language proficiency tests. In this situation, the whole teaching course may let students feel tired about and quite defensive to the listening class, which result in their poor listening level on the contrary. Therefore, a proper teaching way to improve students' listening and speaking level is particularly important. This paper tries to explore an effective listening teaching mode with the constructivism theory as the guidance.

\section{Constructivism Theory}

Constructivism theory originates in the 1980 s, which is also known as structuralism and is a branch of cognitive psychology. J. Piaget, O.Kernberg, R.J.Sternberg, D.Katz and Vygotsky are eminent figures in the development of constructivism theories. Piaget is the most important founders of constructivism, who considers that the learners will gradually build up their knowledge about the external world and develop their cognitive structure in the process of interaction with the surrounding environment. Based on this theory, Kernberg made further studies on the nature and the development conditions of cognitive structure; Sternberg and Katz explored how people dominate their cognitive process. Vygotsky, who is well known as a psychologist, pioneer in social constructivism and situated learning theory research, has proposed the "socio-historical" development theory, acknowledging that the higher psychological function is an arbitrary psychological process which is not inherited from themselves but produced and developed in the process of interaction with the people around them and is subject to the constraints of human cultural history. All these theories laid the foundation to the constructivism theory.

\section{Eminent Viewpoints on Teaching in Constructivism Theory}

Constructivism holds that the learners usually obtain certain knowledge through sense-making in certain scenario with the help of necessary learning materials and other people. Therefore, constructivism theory emphasizes that teaching need the following aspects: be student-oriented, conducted in a realistic scenario, collaboration and sense-making etc.

First, the constructivism emphasizes that the teaching should be student-oriented, which means that students should not be only passive recipients to knowledge, but actively construct their own knowledge structure through sensemaking. Second, constructivism advocates that the teaching activities should be carried out in the realistic scenario, since only this kind of scenario will be beneficial for students to complete the sense-making. Besides, the teaching design should consider how to setup the context for sense-making, and should take the setup of situations as the important part of teaching design. Third, the constructivism emphasizes the importance of collaboration, which students should insist on throughout the whole learning process. For example, in the process of collecting and analyzing the necessary study materials, proposing and verifying the assumption, the evaluation of learning outcomes, till the final sense-making, the collaboration always plays an important role. Finally, constructivism advocates the ultimate goal of the learning process should be the process of sense-making. Meanwhile, teachers should assist students in sense-making in their learning process, which is to help the students to have more indepth understanding on the nature of things in what they have learned and the links between different things.

\section{Constructivism Listening Teaching}

\section{A. Student-Oriented and Teacher Assisted Teaching}

Constructivism advocated that learning is not a simple teaching course that teachers pass the knowledge to the students, but a process that students construct their own knowledge structure. Students should not be passive recipients to information, and they should actively construct their own knowledge. In the traditional listening course, teachers are the only center roles and they will usually do the following things successively: play the tape, repeat playing tape for several times, announce the correct answers to students, and finally tell the students what the people in the dialogue has talked about. In this process, as the students are the passive recipients to knowledge from beginning to end, they will be easily fatigue, unable to focus, feel no interest, and finally become 
disgust to the class. Constructivism emphasizes learners' center roles and teachers' supporting roles in the learning process, and meanwhile proposes that the students are the main subjects who contribute to the sense-making but not the passive recipients from external influence and spoon-feed learners; and stresses that teachers only help and promote sense-making and they are not responsible of teaching and indoctrinating (Wenxia Zhang, 2005). Therefore, taking students as the center role in the learning and sense-making will significantly improve their enthusiasm and interest in learning. For example, you can allow students to lookup the relevant knowledge before listening to the tapes. You can also use some multimedia software to listen to certain materials and make excises according to specific circumstances. Students can freely regulate their own process, and discuss with classmates or teachers when they meet some problems, and finally summarize the important point on listening and complete the excises in the textbook. You can also assign students to explain what they hear or make some role-play exercises, so as to fully exert their center roles.

In his famous Zone of Proximal Development (ZPD) theory, Vygotsky believed that as the teachers and students are in a "peer" relationship, the teaching process should be the interaction activity between teachers and students, and suggested that teachers should provide students with appropriate guidance and assistance and ultimately shift the responsibility of learning gradually to the students (Ying Zou, 2009). Therefore, taking students as the center role does not mean teacher will totally not interfere with students' all activities, but only act as a peer to give appropriate assistance, guide and assist students in listening learning, and consequently deepen students' learning. Before listening to materials, the teacher can use the linguistic scheme with fixed phrases or idioms and grammatical points, the form scheme indicating the forms of listening materials, and the content scheme with background knowledge, so that the content on the textbook can be connected with the knowledge that students grasped, so as to stimulate students to recall their impression on knowledge and form new schema, which will effectively improve students' listening ability. During listening exercises, students can ask teachers the problems they encountered at any time, and teachers should timely give the answers, through this way students won't feel frustrated and will improve confidence.

\section{B. Setup Realistic Scenario and Stimulate Students' Interest}

Listening usually is the most difficult part for students to master in learning a foreign language. However, in some listening classes, the only way of practicing for students is to listen to the materials with headphones, so when they meet some points that they don't understand they will be hard to concentrate what is talking about next in the listening materials. Meanwhile, to let students pass the proficiency test, some teachers may arrange for exercises specific to proficiency test during the whole class, which makes the students lose their interests in listening classes and lack of motivation to overcome difficulties.

In constructivism, it holds that learners generally obtain their knowledge in certain scenario through sense-making, with the help of teachers and students, by utilizing some necessary materials and information. Therefore, teachers should setup appropriate context that is easy for learners to complete sense-making. For example, you can set the background as when students are going to study abroad, and then set the contents as taking place in airports, banks, shopping malls, restaurants and hospitals etc., so that students will better understand what they need to master in these realistic scenarios combining with certain videos, so as to stimulate students' interest, and give guidance to students to actively try to understand the contents.

Multimedia approach should be made fully use of in teaching, since watching movies, television, cartoon, documentaries etc. will introduce the true daily-life scenario that foreigners lives in into the classroom, which will allow students to quickly apply their knowledge after learning.

\section{Encourage Self-Study and Collaborative Learning to Improve Comprehensive Capacity}

Piaget advocated the discovery learning and he stressed that the academic knowledge should not be deemed as absolute truth, and learners should actively construct their knowledge structure through self-direction and peer manner. Therefore, the ultimate goal in education should be developing learners' autonomy (Ying Zou, 2009). In listening teaching, teachers can propose topics or assign certain tasks for students to independently make scheduling, lookup relevant documents, manage their knowledge, and consolidate their listening strategies. At the same time, teachers can use the heuristic method, leading the students to be the center roles in learning, guiding students to ask questions and solve problems so as to improve students' self-study ability. In the learning process, teachers should on one side prepare sufficient audio recordings, videos, multimedia courseware etc. resources to assist students' self-study; on the other hand, students should consciously make use of foreign language news, television programs or websites about foreign language study for their self-study. Collaborative study in listening should never be ignored. Constructivism believed that the sense-making is not completely independent from us but arises from our construction process, and everyone may understand differently on things, so in teaching the collaboration between students are quite necessary so that each one will see the different points of view from himself. Therefore, collaborative study is particularly important and teachers should encourage students for collaborative study in listening teaching. For example, teachers can instruct the dialogue themes to students and divide students into several groups discussing the possible vocabulary, grammar, contents in this theme, which may decrease the difficulty when students begin to listen. You can also organize students for group discussions after listening so that students can timely discuss what they can understand and 
ask questions about what they don't understand, and then work on the excises in textbook and offer their answers as a team. In the teaching process, teachers can take task-based approach, which means that teachers ask questions or assign tasks to students and students should complete the task as a team and finally make performance or report. After a period of study, teachers can also organize students to attend debates, roleplays, dubbing and other games, so that students will improve their comprehensive capabilities in listening, speaking, reading and writing in collaborative study.

\section{Identify Learning Goals and Evaluate Objectively}

As traditional listening teaching design focuses on the teaching objectives, and the ultimate goal of constructivism is to complete the sense-making, therefore the sense-making activities should be on the basis of teaching objectives. During this process, a scientific evaluation system should be built up, which may use the self-assessment and mutual assessment objectively reflecting students' contribution to collaborative study and individual sense-making progress, so that they will be clarified with their future major studying points and ultimate goals.

\section{Constructivism Listening Teaching Cases}

The following specific cases are used to explore the constructivism theory application in listening teaching.

1) Setup teaching objectives: understand and master the expressions about dining in restaurant.

2) Setup realistic scenario: play a video about two persons having diner in the restaurant to students.

3) Classroom implementation: pay attention to students' center roles and the assistance of teachers, encouraging selfstudy and collaborative study.

First, set the course topic as "in restaurant". You can give the topic for the next class to students at the end of class, and group the students into different teams so as to predict the related vocabulary, expressions and prepare relative knowledge points. At the beginning of course, you can arrange a student on behalf of his/her team to make report on the knowledge points that has been collected and collated. Teachers then can explain the specific points in this course, for example, you can tell the students the dining process in restaurants, which may involve some important expressions, the etiquette when dining in the restaurant, and what should they pay attention.

Second, teachers can organize students in groups to have role plays taking "dining in restaurant" as the topic, and then let students listen and practice by themselves. During this period, teachers can conduct inspection around and answer the questions raised by students. The students can be further divided into several groups to continue listening and have mutual discussions.

Finally, you can let students express their opinions and listen to the viewpoints from each other, and complete the tasks assigned from teachers together. For example, students can have role plays and perform the restaurant dining process, the possible problems might meet and corresponding solutions etc.

4) Evaluation. Students should collate and make reports on their tasks in groups. Student's self assessment and mutual assessment, and teacher's assessment will be necessary, so that the sense-making status for students can be evaluated.

Generally speaking, constructivism emphasizes that students should actively learn and construct their own knowledge structure in accordance with specific and realistic scenario, and is of important directive significance to listening teaching as the teaching methods that some teachers adopted may let student become passive recipients to knowledge. If we can actively explore the constructivism theory and then apply in daily listening teaching, it will improve the listening teaching effect effectively.

\section{References}

[1] K.K. He, "Constructivism - the Theoretical Basis for Teaching Reform", Science Lesson, vol. 12, pp. 22-23, 2003.

[2] K.K. He, "The Teaching Mode, Teaching Methods and Teaching Design for Constructivism", Journal of Beijing Normal University, vol. 5, pp. 76-81, 1997.

[3] W.X. Zhang, "The Influence of Behaviorism and Constructivism Learning Theory on Foreign Language Teaching", Foreign Language Education, vol. 3, pp. 69-71, 2005.

[4] W.Q. Cui, "Constructivism Application in College English Listening Teaching", Journal of Language and Literature Studies, vol. 6, pp. 155160, 2009.

[5] Z.L. Cai, "A Study on Japanese Listening Multimedia Teaching Mode in Higher Schools under Constructivism Theory," Journal of Tongling Vocational \& Technical College, vol. 2, pp. 63-65, 2010.

[6] Y. Zou, "A Comparative Study of the Constructivist Views Between Piaget and Vygotsky," Foreign Language Research, vol. 5, pp. 117-120, 2009.

[7] W.D. Yang and J. Zhao, "A Study on Task-Based and Interactive Teaching Mode in Constructivism," Foreign Language Education, vol. 5, pp. 57-60, 2011.

[8] Y. Kafai \& M. Resnik, Constructivism in Practice: Designing, Thinking and Learning in a Digital World, Lawrence Erlbaum Associations, 1996.

[9] C. Dede, "The Evolution of Constructivist Learning Environments: Immersion in Distributed Virtual Worlds", Educational Technology, vol. 5, pp. 46-52, 1995. 